AJS Review 42:2 (November 2018), 489

(C) Association for Jewish Studies 2018

doi:10.1017/S036400941800048X

ABSTRACT OF HEBREW ARTICLE

\title{
Rabbi Eliezer Ashienazi's Commentary on the Garden of Eden Story: Between EXeGesis AND Religious ThOUght Michal Ohana
}

This essay investigates Rabbi Eliezer Ashkenazi's commentary on the story of the Garden of Eden, first exploring his method of Bible commentary in general. In his interpretation of the Bible he vehemently distances himself from allegorical interpretation that abandons the plain meaning of the text, and holds that while biblical stories function as allegory (mashal), they all, without exception, actually occurred as written. Ashkenazi's interpretation of the Garden of Eden episode serves as a platform for presenting his thoughts regarding two of the main issues that occupied Jewish thinkers during the Middle Ages and the early modern period: human perfection and the proper balance between the divine Torah and intellectual inquiry. The examination of Ashkenazi's reading of this biblical episode shows that his perspective concurs with that of his colleagues in the Sephardic Diaspora throughout the Ottoman Empire, who identified with the moderate camp of the Sephardic philosophical tradition, which sees man as the purpose of creation and believes Torah study should precede philosophical inquiry.

Michal Ohana

Bar-Ilan University 